\title{
STUDI TENTANG FENOMENA BORNEO VORTEX TERHADAP VARIABILITAS AWAN DI KALIMANTAN BARAT (STUDI KASUS TANGGAL 11-13 JANUARI 2018)
}

\author{
KHALID FIKRI NUGRAHA ISNOOR*, PRASETYO UMAR FIRDIANTO, \\ ASRI SUSILAWATI \\ Program Studi Meteorologi, \\ Dosen Program Studi Meteorologi,
}

Jl. Perhubungan I No. 5 Pondok Betung, Pondok Aren, Bintaro-Tangerang Selatan 15221

*email : khalidfikri16@gmail.com

\begin{abstract}
Abstrak.Pada tanggal 11-13 Januari 2018 telah terjadi hujan lebat dan menyebabkan banjir bandang di beberapa wilayah Kalimantan Barat. Hal ini disebabkan curah hujan sangat tinggi yang mencapai $212 \mathrm{~mm} / \mathrm{hari}$. Diketahui bahwasanya terjadi fenomena Borneo Vortex di wilayah perairan Pulau Kalimantan. Tujuan dari penelitian ini adalah untuk mengetahui pengaruh fenomena Borneo Vortex terhadap variabilitas awan saat kejadian tersebut. Data yang digunakan adalah Satelit Himawari-8, data curah hujan di delapan titik pengamatan dan Sinoptik, Streamline, dan Radiosonde. Metode yang digunakan adalah teknik HCAI dan Split WindowsSatelit Himawari-8, analisisskala regional, sertaanalisisskalalokal. Hasilnya adalah Borneo Vortex memberikan pengaruh yang signifikan terhadap kondisi awan di wilayah tersebut. Awan terkonsentrasi dalam sistem tertutup dengan didominasi oleh awan konvektif tebal (dense) dan Cumulonimbus pada ketinggian lebih dari $16 \mathrm{~km}$, suhu puncak awan mencapai $-82^{\circ} \mathrm{C}$ yang lebih dari 3 jam. Selain itu, fenomena Siklon Tropis Joyce di Barat Laut Australia turut mempengaruhi sirkulasi udara.
\end{abstract}

\section{Kata kunci :Borneo Vortex, Cumulonimbus, Curah hujan, Variabilitas}

\begin{abstract}
On 11-13 January 2018 there has been heavy rains and caused flash floods in some areas of West Kalimantan. This is due to very high rainfall reaching $212 \mathrm{~mm} /$ day. It is known that Borneo Vortex phenomenon occurs in the territorial waters of Kalimantan Island. The purpose of this research is to know the influence of Borneo Vortex phenomenon to cloud variability when the incident. The data used are Himawari-8 Satellite, rainfall data in eight observation points and Synoptic, Streamline, and Radiosonde. The methods used are HCAI and Split Windows Satellite Himawari-8, regional scale analysis, and local scale analysis. The result is that Borneo Vortex has a significant effect on cloud conditions in the region. Clouds are concentrated in closed systems dominated by dense convective clouds (dense) and Cumulonimbus at an altitude of more than $16 \mathrm{~km}$, the cloud top temperature reaching $-82^{\circ} \mathrm{C}$ over 3 hours. In addition, the phenomenon of Tropical Cyclone Joyce in the Northwest of Australia contributes to air circulation.
\end{abstract}

Keywords :Borneo Vortex, Cumulonimbus, Rainfall, Variability

\section{Pendahuluan}

Indonesia merupakan wilayah dari gugusan ribuan pulau besar maupun kecil yang dipisahkan oleh laut dan samudra, sehingga disebut sebagai Maritime Continent [1]. Menurut Aldrian [2], Indonesia merupakan sebuah benua maritim yang 
berada di wilayah tropis dengan letak diantara dua benua dan dua samudra. Hal ini menyebabkan Indonesia memiliki banyak fenomena cuaca yang menarik untuk dikaji. Benua Maritim Indonesia (BMI) dipengaruhi oleh angin regional dari perbedaan tekanan Asia dan Australia atau yang biasa disebut monsun.

Menurut Zakir dkk[3], monsun adalah suatu pola sirkulasi angin yang berhembus secara periodik pada suatu periode (minimal 3 bulan) dan pada periode lain polanya akan berlawanan. Indonesia memiliki dua jenis monsun, yaitu monsun Asia dan monsun Australia. Ketika monsun Asia aktif maka terjadi musim penghujan dan ketika monsun Australia aktif maka terjadi musim kemarau di BMI. Vortex merupakan salah satu fenomena saat monsun dingin Asia aktif yang terjadi di barat laut pulau Kalimantan yang sering dikaitkan dengan aktifitas hujan deras dan bencana banjir[4]. Fenomena vortex tersebut dapat dinamakan dengan Borneo Vortex.

Pada tanggal 11-13 Januari 2018 terjadi fenomena Borneo Vortex di Bagian Barat Pulau Kalimantan. Hal tersebut menyebabkan kejadian hujan lebat disertai angin kencang dan petir. Akibatnya terjadi banjir yang cukup besar di beberapa wilayah Kalimantan Barat, yaitu Sambas, Singkawang, Bengkayang, Mempawah, Kubu Raya, Pontianak, Kayong Utara dan Ketapang. Saat kejadian, di sekitar wilayah sekitar terjadinya Borneo Vortex terdapat kumpulan awan konvektif tebal yang diduga sebagai penyebab terjadinya kondisi cuaca ekstrem [5]. Oleh karena itu, dilakukan analisis terhadap fenomena Borneo Vortex saat kejadian banjir di Kalimantan Barat pada waktu tersebut.

\section{Metode Penelitian}

Data SPL yang digunakan berasal dari data reanalisis resolusi tinggi AVHRRNOAA yang dapat diunduh melalui www.esrl.noaa.gov. Data tersebut memiliki resolusi sebesar $0,25^{\circ} \times 0,25^{\circ}$ dengan format .nc. Kemudian data dipetakan menggunakan software Surfer 11 secara rata-rata harian selama kejadian Borneo Vortex, yaitu tanggal 11-13 Januari 2018. Analisis SPL perlu dilakukan untuk mengetahui kondisi kondisi suhu permukaan laut yang berpengaruh terhadap interaksi laut dan atmosfer di wilayah tersebut.

Data Streamline yang digunakan berasal dari Bureau of Meteorology (BOM) Australia yang dapat diunduh melalui www.bom.gov.au. Data tersebut diambil saat periode kejadian Borneo Vortex, yaitu tanggal 11-13 Januari 2018 di Kalimantan Barat. Analisis data Streamline perlu dilakukan karena untuk mengetahui aliran sirkulasi udara saat kejadian badai tersebut. Selain itu dapat digunakan untuk mengetahui wilayah yang berpotensi mengalami perubahan cuaca secara signifikan.

Data Radiosonde yang digunakan berasal dari Stasiun Meteorologi Pontianak (WMO 96581) pada jam 00.00 UTC dan 12.00 UTC untuk tanggal 11-13 Januari 2018. Data Radiosonde dapat diunduh melalui www.weather.uwyo.edu dalam format .txt dan kemudian diolah menggunakan software RAOB 5.7. Analisis data Radiosonde perlu dilakukan karena untuk mengetahui labilitas udara atas saat terjadinya Borneo Vortex. Digunakan data dari Stasiun Meteorologi Pontianak karena merupakan Stasiun pengamatan udara atas terdekat dari wilayah terjadinya 
fenomena tersebut sehingga diharapkan mampu mempresentasikan tingkat kestabilan udara atas yang dinyatakan dengan indek KI, LI, TT, SWEAT, dan CAPE.

Data Satelit yang digunakan berasal dari data Satelit Himawari-8 Kanal IR yang diperoleh dari Badan Meteorologi Klimatologi Geofisika (BMKG). Data tersebut dalam format .z dan .bin dan diolah menggunakan software GMSLPC dan GMSLPD (SATAID). Data tersebut mempunyai ripitasi tiap 10 menit selama periode Borneo Vortex, yaitu 11-13 Januari 2017. Analisis data satelit perlu dilakukan untuk mengetahui kondisi perawanan saat terjadi fenomena tersebut. Untuk mengidentifikasi mikrofisis awan dapat dugunakan metode High-resolution Cloud Analysis Information.

Data curah hujan observasi digunakan untuk mengetahui jumlah curah hujan yang turun ketika kejadian banjir di Kalimantan Barat. Pengukuran dilakukan di 8 titik pengamatan agar hasil yang diperoleh representatif. Sedangkan, estimasi curah hujan dari Satelit digunakan untuk mengetahui distribusi curah hujan di wilayah tersebut. Data sinoptik digunakan untuk mengetahui kondisi meteorologi permukaan sehingga dapat diketahui perubahan parameter yang disebabkan oleh parameter tersebut.

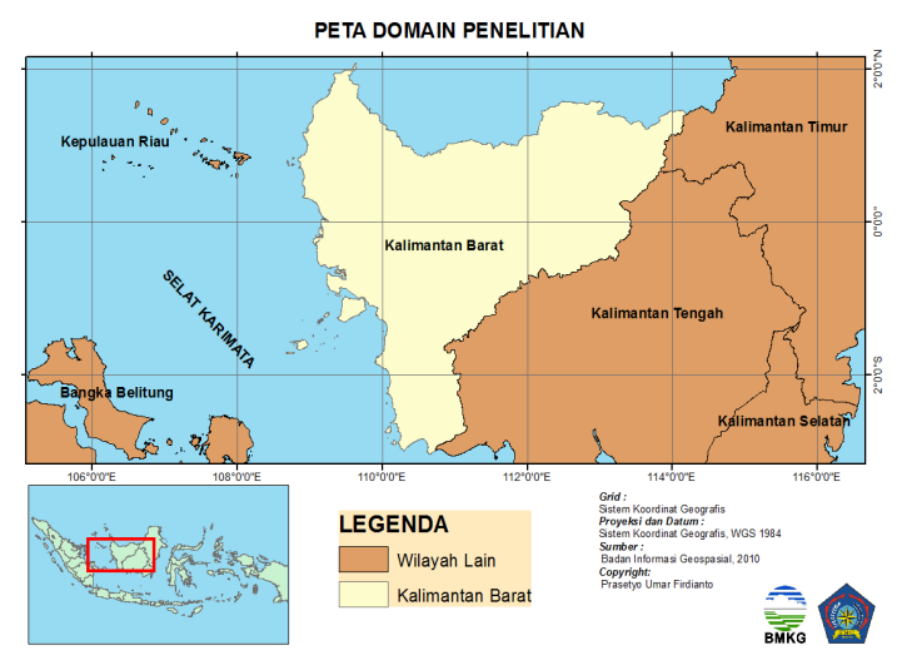

Gambar 1.Wilayah Kajian Kalimantan Barat

Wilayah kajian berada di Kalimantan Barat pada $2,46^{\circ} \mathrm{LU}-3,70^{\circ} \mathrm{LS}$ dan $108,03^{\circ}$ BT-114,90 BT. Titik yang bertanda merah merupakan titik terjadinya Fenomena Borneo Vortex tanggal 11-13 Januari 2018.

\section{Hasil dan Pembahasan}

\subsection{Identifikasi Fenomena Borneo Vortex}

Gambar 2. Diatas menunjukan Stream line Gradient Level Wind saat terjadinya fenomena Borneo Vortex. Terlihat bahwa terdapat pusaran dengan pusat tekanan rendah berada di wilayah perairan barat laut Pulau Kalimantan. Arah putaran pusaran berlawanan arah dengan jarum jam yang menjadi karakteristik khusus pada fenomena Borneo Vortex. Intensitasnya cenderung menguat hingga tanggal 
13 Januari 2018. Pada daerah pusat tekanan rendah tersebut, terjadi pergerakan udara secara konvergensi. Massa udara basah akibat Suhu Permukaan Laut hangat di bagian Utara dan Selatan Pulau Kalimantan, tertarik kearah tekanan rendah tersebut. Akibatnya terjadi aliran udara secara konvergensi yang menyebabkan udara bergerak keatas (ascent). Sehingga muncul awan konvektif yang tumbuh karena gaya dorongan keatas tersebut. Umumnya, awan tersebut sangat besar dan tebal yang pada akhirnya dapat menyebabkan terjadinya hujan lebat. Selain itu, teramati juga terdapat Siklon Tropis Joyce di bagian Barat Australia. Hal tersebut menambah tarikan massa udara yang kuat di atmosfer. Sehingga membuat kondisi atmosfer semakin tidak stabil dan memperkuat pengaruh konvektif di wilayah Kalimantan Barat.
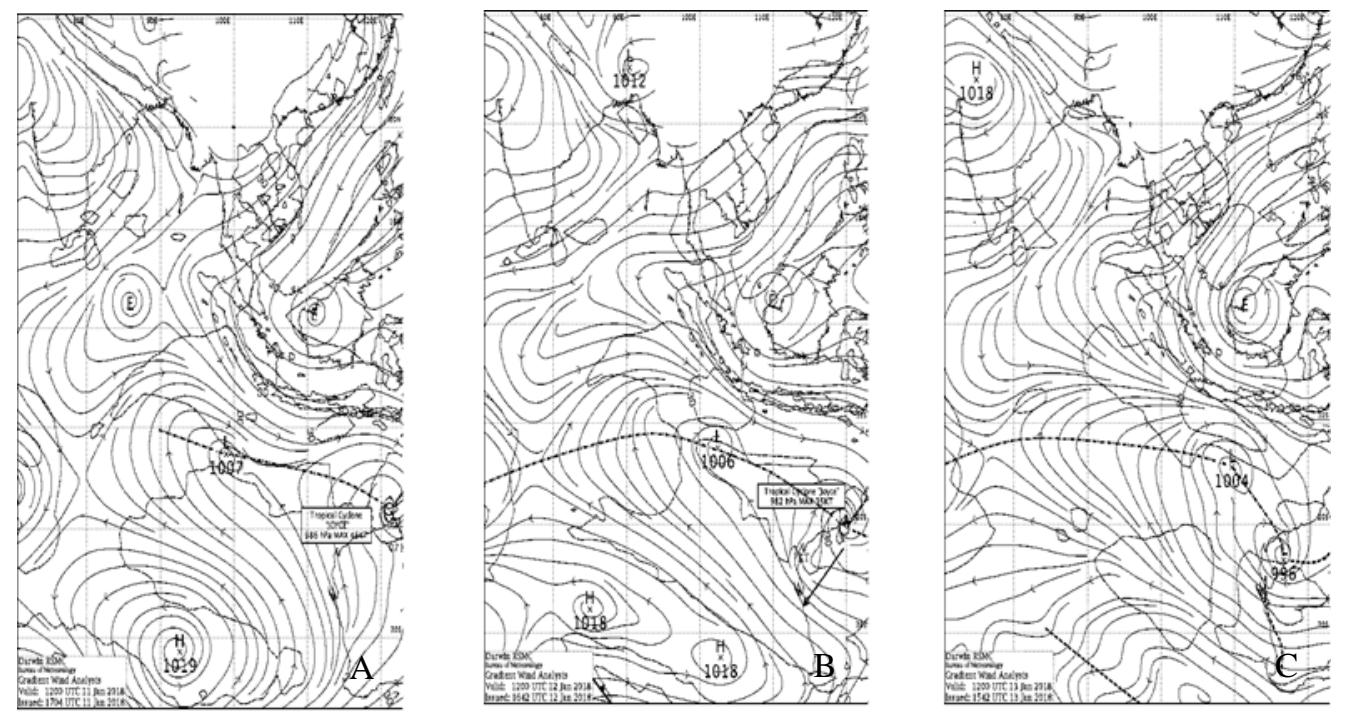

Gambar 2.Streamline Saat Kejadian Borneo Vortex Bulan Januari 2018. (a) Tanggal 11. Tanggal 12. (c) Tanggal 13

(b)

\subsection{AnalisisSkala Regional}

\subsubsection{AnalisisSuhuPermukaanLaut (SPL)}

Analisis SPL digunakan untuk menentukan anomaly suhu permukaan laut pada saat sedang terjadi Borneo Vortex di tanggal penelitian. Dari anomaly tersebut dapat dicari tahu bagaimana keadaan kondisi muka laut yang dapat mempengaruhi pertumbukan variabilitas awan di lokasi penelitian. (Gambar 3.) menunjukan anomali dan Suhu Permukaan Laut selama periode Borneo Vortex. Dari Gambar 2a menunjukan Suhu Permukaan Laut di sekitar wilayah Kalimantan Barat. Terlihat bahwa Suhu Permukaan Laut tinggi di bagian Utara dan Selatan Pulau Kalimantan. Sedangkan Suhu Permukaan Laut rendah di bagian Barat Pulau Kalimantan. Selisih antara Suhu Permukaan Laut tersebut cukup tinggi yang mencapai lebih dari $2{ }^{\circ} \mathrm{C}$. Sedangkan dari Gambar 3b menunjukan anomali Suhu Permukaan Laut dari nilai normalnya. Teramati dibagian Selatan dan Utara Pulau Kalimantan, mempunyai anomali yang cukup tinggi yaitu mencapai $1{ }^{\circ} \mathrm{C}$. Dengan demikian karena sekitar Pulau Kalimantan didominasi oleh Suhu Permukaan yang tinggi, maka suplai uap air semakin banyak dan memicu terjadinya wilayah 
tekanan rendah yang salah satu hasilnya adalah terbentuk fenomena Borneo di bagian Barat Pulau Kalimantan.
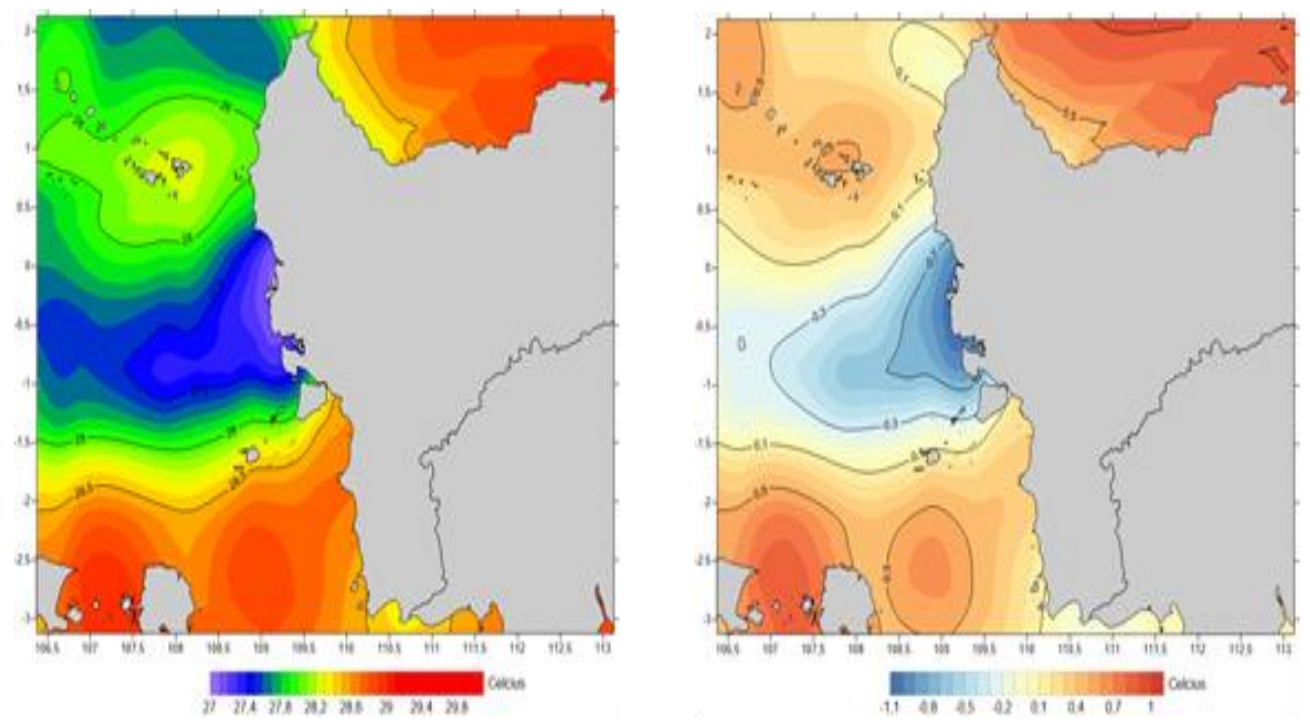

Gambar 3.Suhu Permukaan Laut tanggal 11-13 Januari 2018 (a) Suhu Permuakaan Laut Rata-rata Harian, (b) Anomali Suhu Permukaan Laut Rata-rata Harian

\subsection{AnalisisSkalaLokal}

\subsubsection{AnalisisUdaraAtas}

Gambar 4 dibawah menunjukan yang cukuptinggi, ditunjukan dengan adanya kecenderungan grafik vertical suhu dan titik embun cenderung berhimpit, serta adanya indeks labilitas yang menunjukan nilai yang memungkinkan kondisi cuaca cenderung labil. Sementara itu, pada tanggal 13 pengamatan udara atas hanya terbatas sampai lapisan ketinggian $600 \mathrm{mb}$ yang dimungkinkan terjadinya missing. Tetapi dilihat dari beberapa parameter yang teramati, kondisi udara masih cenderung labil, dan dapat berdampak kepada pertumbuhan awan-awan konvektif yang tinggi seperti Cumulonimbus.
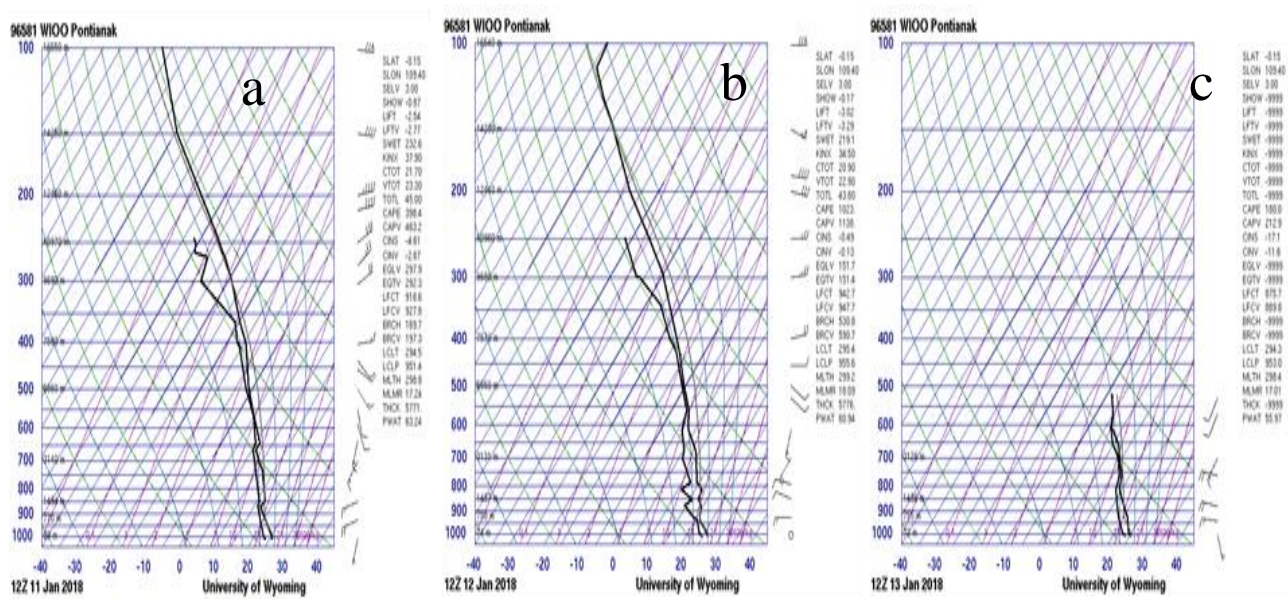

Gambar 4. PengamatanUdaraAtasdenganRadiosondeStasiunMeteorologi Pontianak

(a) Tanggal 11. (b) Tanggal 12. (c) Tanggal 13 
Berdasarkan pengamatan udara atas pada tanggal 11 Januari 2018 dan 12 Januari jam 00.00 UTC, tercatat nilai K indeks pada pukul 00.00 UTC sebesar 37,9 dan pada tanggal 12 jam 00.00 UTC K Indeks sedikit menurun menjadi 34,5, hal ini menunjukan adanya potensi terjadinya pertumbuhan awan konvektif dan memungkinkan terjadinya thunderstorm sebesar 60-80\%. Lifted Indeks pada tanggal 11 sebesar $-2,54$ dan pada tanggal 12 menigkat sebesar -3,02 yang menunjukan bahwa kondisi udara tidak stabil memungkinkan adanya kejadian thunder storm. Nilai CAPE pada tanggal 11 tercatat sebesar 398 dan meningkat pada tangga 12 sebesar 1023 hal tersebut menunjukan adanya potensi pertumbuhan awan konvektif kuat di wilayah penelitian. Nilai CIN pada tanggal 11 sebesar -4,61 dan pada tanggal 12 menurun sebesar -0,62 hal ini juga menunjukan adanya energy pertumbumbuhan awan yang berkurang namun kondisi udara masih dapat dikatakan cenderung labil. Sedangkan nilai Total Total Indeks pada tanggal 11 sebesar 45 dan pada tanggal 12 sebesar 43,6. Dari indeks labilitas dibawah dapat dikatakan puncak udara labil sudah terlihat pada tanggal 11 Januari.

Tabel 1. Indek Hasil Pengamatan Udara Atas dengan Radiosonde

\begin{tabular}{cccccccc}
\hline Tgl & KI & SI & LI & TT & SWEAT & CAPE & CIN \\
\hline 11 & 37,9 & $-0,87$ & -2.54 & 45 & 232,6 & 398,4 & $-4,61$ \\
12 & 34,5 & $-0,17$ & $-3,02$ & 43.6 & 219,1 & 1023 & $-0,49$ \\
13 & - & - & - & - & - & 180 & $-17,1$ \\
\hline
\end{tabular}

\subsubsection{Analisis Data Observasi (Sinoptik)}

Berdasarkan Tabel 2. menunjukan pengamatan meteorologi permukaan (sinoptik) di Stasiun Meteorologi Pontianak pada tanggal 11, 12, dan 13. Terlihat bahwa selama tanggal tersebut, tutupan awan rata-rata harian mencapai 7/8 Okta dengan didominasi oleh awan rendah, yang berarti bahwa setiap hari di wilayah pengamatan hampir selalu tertutup awan. Awan yang mendominasi dari hasil pengamatan adalah awan Cumulonimbus dan awan stratiform yang tebal. Awan ini pada umumnya bersifat basah dengan kandungan uap air yang tinggi. Sehingga berpotensi membawa massa udara lembab dan menyebabkan hujan dengan intensitas tinggi. Tekanan udara permukaan cenderung rendah, yaitu dapat mencapai $1008,8 \mathrm{mb}$. Sedangkan suhu udara maksimum hanya sampai $31,5{ }^{\circ} \mathrm{C}$ dengan suhu udara minimum mencapai $23{ }^{\circ} \mathrm{C}$. Kelembaban udara rata-rata harian yang sangat tinggi yaitu mencapai $94,6 \%$, yang berarti kondisi udara permukaan pada saat tersebut sangat basah dan lembab. Dan kecepatan angin yang dapat mencapai $20 \mathrm{Km} / \mathrm{Jam}$. Angin permukaan dalam kategori tersebut termasuk dalam angin kencang sehingga berpotensi menyebabkan angin yang lebih kencang di lapisan yang lebih tinggi. 
Tabel 2. PengamatanSinoptikStasiunMeteorologi Pontianak

\begin{tabular}{|c|c|c|c|c|c|c|c|c|c|c|c|c|}
\hline \multirow{2}{*}{$\begin{array}{c}\mathrm{Tg} \\
1\end{array}$} & \multicolumn{2}{|c|}{ Suhu $\left({ }^{\circ} \mathrm{C}\right)$} & $\begin{array}{c}\text { Rat } \\
\mathrm{a} \\
\mathrm{Rh}\end{array}$ & \multicolumn{2}{|c|}{$\begin{array}{l}\text { Angin } \\
(\mathrm{Km} / \mathrm{J})\end{array}$} & \multirow{2}{*}{$\begin{array}{c}\text { Rata } \\
\begin{array}{c}\text { Tekana } \\
\mathrm{n}\end{array} \\
(\mathrm{mb})\end{array}$} & \multirow{2}{*}{$\begin{array}{c}\text { Total } \\
\text { Awan } \\
\text { (Okta } \\
\text { ) }\end{array}$} & \multirow{2}{*}{$\begin{array}{c}\begin{array}{c}\text { Awan } \\
\text { Renda } \\
\text { h }\end{array} \\
\text { (Okta) }\end{array}$} & \multirow{2}{*}{$\begin{array}{c}\text { Jam } \\
00 \\
\text { UT } \\
\text { C }\end{array}$} & \multirow{2}{*}{$\begin{array}{c}\text { Jam } \\
06 \\
\text { UT } \\
\text { C }\end{array}$} & \multirow{2}{*}{$\begin{array}{c}\text { Jam } \\
12 \\
\text { UT } \\
\text { C }\end{array}$} & \multirow{2}{*}{$\begin{array}{c}\text { Jam } \\
18 \\
\text { UT } \\
\text { C }\end{array}$} \\
\hline & $\begin{array}{c}\mathrm{Ma} \\
\mathrm{x}\end{array}$ & $\begin{array}{c}\mathrm{Mi} \\
\mathrm{n}\end{array}$ & $(\%)$ & Arah & $\begin{array}{c}\mathrm{Ma} \\
\mathrm{x}\end{array}$ & & & & & & & \\
\hline 11 & $\begin{array}{c}31 . \\
5\end{array}$ & $\begin{array}{c}23 . \\
3\end{array}$ & $\begin{array}{c}90 . \\
1\end{array}$ & ENE & 13 & 1010.3 & 7.8 & 5.6 & As & $\mathrm{Cb}$ & $\mathrm{Cu}$ & $\mathrm{Cb}$ \\
\hline 12 & $\begin{array}{c}29 . \\
2\end{array}$ & $\begin{array}{c}23 . \\
4\end{array}$ & $\begin{array}{c}92 . \\
1\end{array}$ & $\begin{array}{l}\text { WS } \\
W\end{array}$ & 13 & 1009.8 & 7.8 & 5.6 & $\mathrm{St}$ & St & $\mathrm{Cu}$ & $\mathrm{Cu}$ \\
\hline 13 & 28 & 23 & $\begin{array}{c}94 . \\
6\end{array}$ & $\begin{array}{l}\text { NN } \\
\text { W }\end{array}$ & 20 & 1008.8 & 7.6 & 5.2 & St & $\mathrm{Cb}$ & $\mathrm{Cb}$ & $\mathrm{Sc}$ \\
\hline
\end{tabular}

Berdasarkan Tabel 3. menunjukan jumlah curah hujan hasil pengamatan di 8 Stasiun Badan Meteorologi Klimatologi Geofisika (BMKG). Pada tanggal 11, curah hujan yang tercatat dapat mencapai $212 \mathrm{~mm} / \mathrm{hari}$ di Stasiun Meteorologi Paloh, Kecamatan Sambas Kalimantan Barat bagianutara. Untuk curah hujan tersebut tergolong sangat tinggi dan ekstrem (BMKG, 2003). Sedangkan tanggal 12 curah hujan mengalami penurunan yaitu menjadi $112,5 \mathrm{~mm} / \mathrm{hari}$ yang terukur di Stasiun Meteorologi Maritim Pontianak. Tetapi masih tergolong curah hujan yang sangat tinggi dan ekstrem. Begitu juga saat tanggal 13, curah hujan mengalami penurunan tapi masih tergolong tinggi dan ekstrem, yaitu mencapai $88,1 \mathrm{~mm} /$ hari. Dilihat dari data curah hujan observasi di beberapa titik Stasiun di wilayah Kalimantan Barat menunjukan pada tanggal 11 - 13 Januari 2018 menunjukan adanya peningkatan curah hujan akibat dipicu oleh kejadian fenomena Borneo Vortex yang terlihat di wilayah perairan barat lau Pulau Kalimantan.

Tabel 3. Curah Hujan Delapan Stasiun Pengamatan BMKG

\begin{tabular}{ccccc}
\hline No. & Lokasi & Tanggal & Tanggal & Tanggal \\
& $\mathbf{1 1}$ & $\mathbf{1 2}$ & $\mathbf{1 3}$ \\
\hline 1 & Stamet Supadio Pontianak & 77,5 & 104,7 & 45,6 \\
2 & Stamet Maritim Pontianak & 76,8 & 112,5 & 88,1 \\
3 & Staklim Mempawah & 77,9 & 60,3 & 65,4 \\
4 & Stamet Paloh Sambas & 212,0 & 7,0 & 35,3 \\
5 & Stamet Nanga Pinoh & 34,2 & 10,7 & 36,2 \\
6 & Melawi & 14,0 & 0,8 & 15,0 \\
7 & Stamet Susilo Sintang & 12,0 & TTU & TTU \\
8 & Stamet Rahadi Osman & & 5,0 & 34,6 \\
\hline
\end{tabular}




\subsubsection{Analisis Citra Satelit}
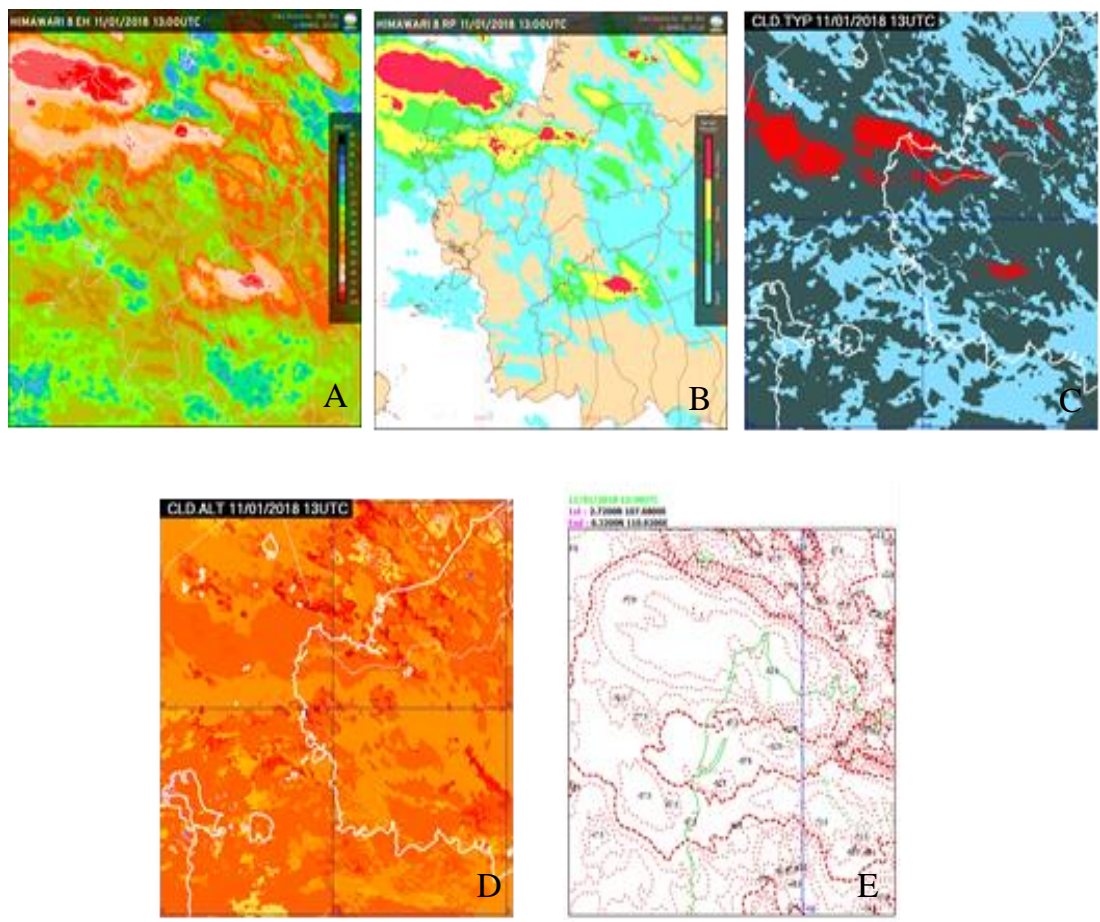

Gambar 5. Mikrofisis Awan Tanggal 11 Januari 2018 dengan Satelit Himawari. (A) Suhu Puncak Awan. (B) Potential Rainfall. (C) Jenis Awan. (D) Ketinggihan Awan (E) Kontur Suhu Puncak Awan
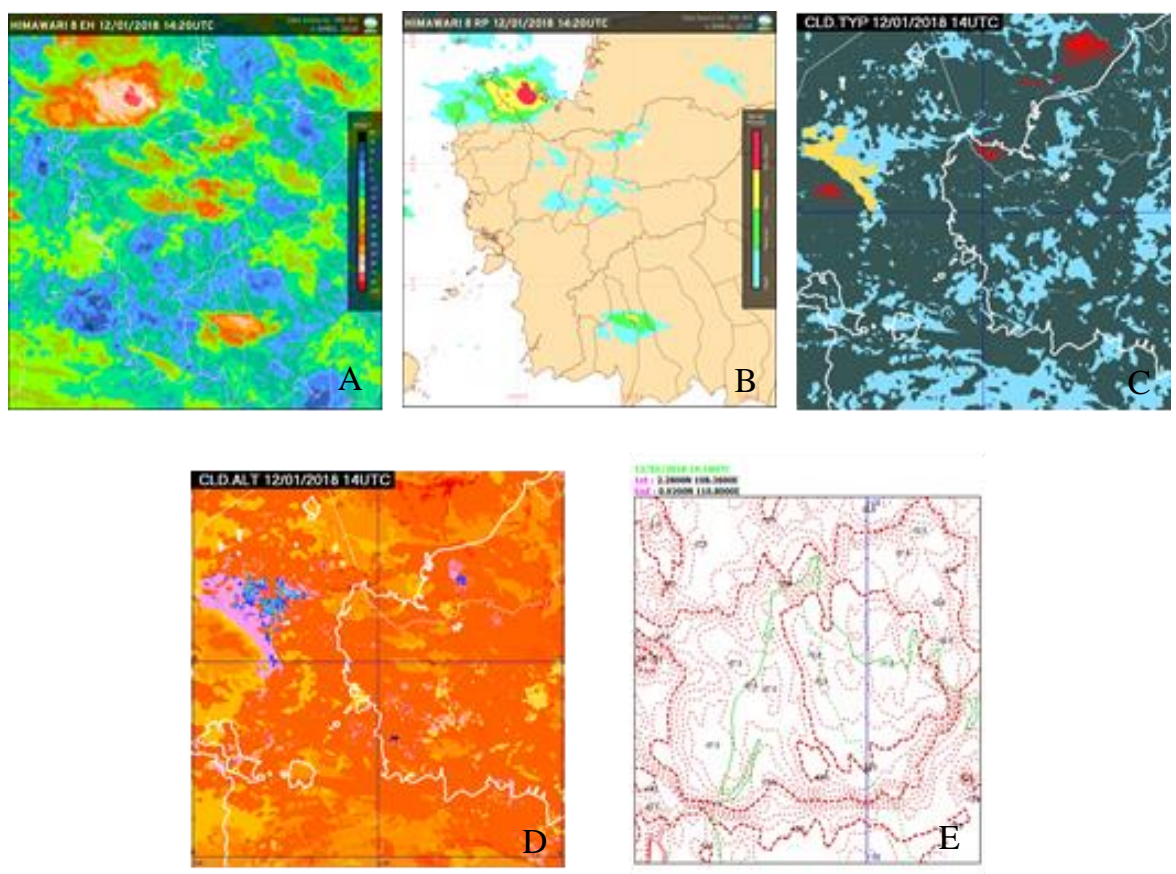

Gambar 6. Mikro fisis Awan Tanggal 12 Januari 2018 dengan Satelit Himawari. (A) Suhu Puncak Awan. (B) Potential Rainfall. (C) Jenis Awan. (D) Ketinggihan Awan (E) Kontur Suhu Puncak Awan 

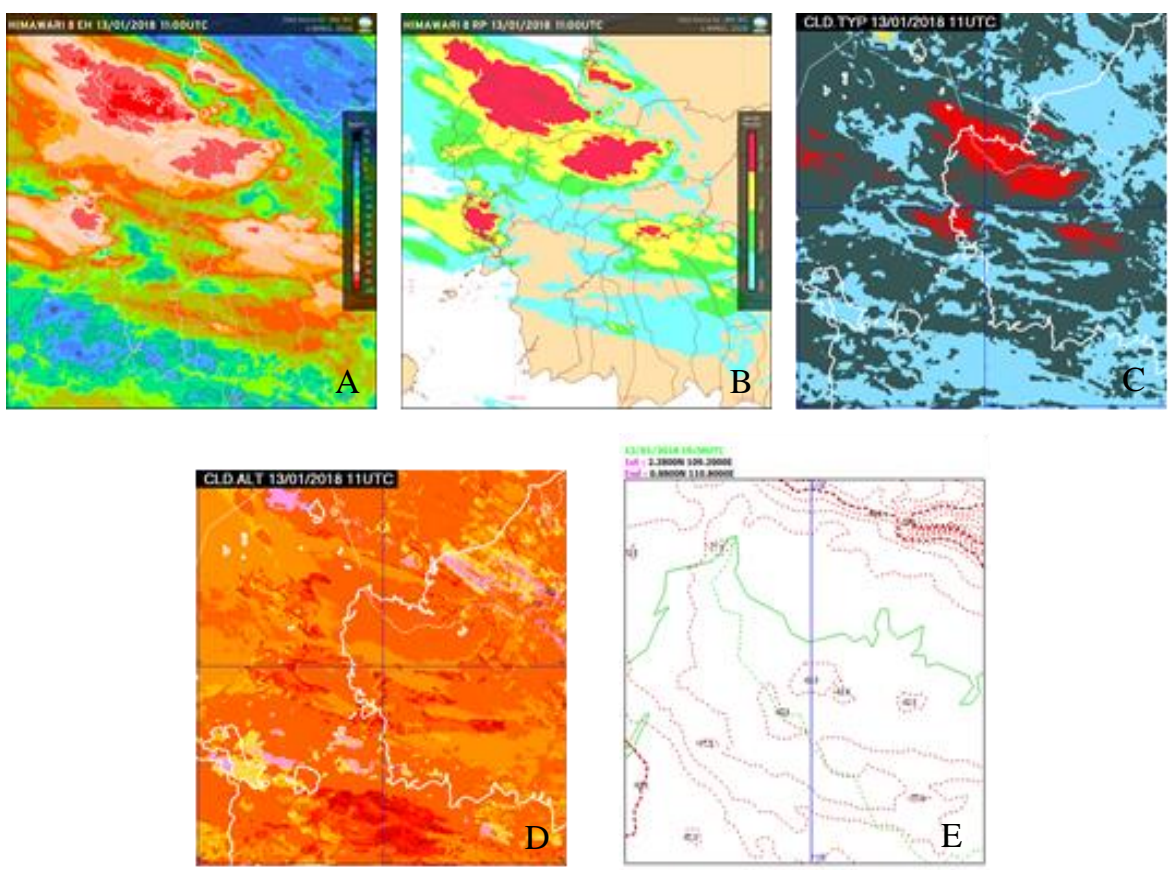

Gambar 7. Mikrofisis Awan Tanggal 13 Januari 2018 dengan Satelit Himawari. (A) Suhu Puncak Awan. (B) Potential Rainfall. (C) Jenis Awan. (D) Ketinggihan Awan (E) Kontur Suhu Puncak Awan

Gambar 5, 6, dan 7 merupakan hasil analisis mikrofisis awan dari Satelit Himawari-8 saat terjadinya fenomena Borneo Vortex di Bagian Barat Pulau Kalimantan. Poin (A) merupakan presentasi distribusi suhu puncak awan yang menyatakan tebal atau tipisnya awan, dan tinggi atau rendahnya awan. Poin (B) merupakan Potential Rainfall yang menyatakan potensi jumlah curah hujan yang turun ke permukaan bumi. Pon (C) merupakan tipe/jenis awan yang digunakan sebagai sarana identifikasi. Point (D) merupakan estimasi ketinggian awan dari permukaan laut. Poin (E) menyatakan kontur suhu puncak awan.

Pada tanggal 11 (Gambar 5.), teramati bahwa gugusan awan yang terbentuk memanjang dengan suhu puncak awan mencapai $-82,5^{\circ} \mathrm{C}$. Awan tersebut berupa awan Cumulonimbus seperti yang diperlihakan oleh (Gambar 5.C)), terlihat adanya awan tebal yang ditunjukandenganwarnamerah yang tersebar di perairanbaratlautPulau Kalimantan dan pumpunanawanbesar yang berada di ujung Kalimantan Barat. Potensi curah hujan lebat tinggi yang menyapu luasan cukup besar. Namun, sapuan awan di wilayah daratan cenderung lebih sedikit daripada di laut. Ketinggian awan dapat mencapai lebih dari $16 \mathrm{~km}$. Pada tanggal 12, teramati adanya penurunan aktivitas perawanan. Hal ini terlihat dengan berkurangnya luasan awan Cumulonimbus (Gambar 6.(C)), namun tetap didominasi oleh awan tebal berupa akan konvektif (dense cloud). Suhu puncak awan menurun menjadi $-77,5^{\circ} \mathrm{C}$ dengan Potential Rainfall yang cenderung menurun. Ketinggian awan dapat mencapai lebih dari $16 \mathrm{~km}$ tetapi cakupan area nya lebih kecil. Dengan demikian, terindikasi intensitas Borneo Vortex yang menurun. Pada tanggal 13, terlihat adanya peningkatan tutupan awan yang hampir menutupi semua wilayah Kalimantan Barat. Awan Cumulonimbus (Gambar 7.(C)) tumbuh membesar dan tebal diikuti oleh awan konvektif (dense cloud) 
lainnya. Potential Rainfall sangat tinggi dengan mencakup luasan wilayah yang besar. Suhu puncak awan mencapai $-82,5^{\circ} \mathrm{C}$ dengan ketinggihan lebih dari $16 \mathrm{~km}$.

\section{Kesimpulan}

Dari uraian diatas, dapat disimpulkan bahwa saat terjadi Borneo Vortex, terdapat pertumbuhan awan konvektif yang sangat tinggi karena adanya tarikan kearah pusat terkanan rendah. Dilihat dari analisis skala regional menunjukan adanya suhu permukaan laut tinggi dibagian utara dan selatan Pulau Kalimantan yang mengindikasikan adanya suplai uap air untuk pertumpuhan awan Cumulonimbus. Dilihatdarianalisisskala local, terdapatvertikalsuhu yang cenderung berhimpit pada tanggal 11 hingga 13 Januari 2018, serta didukung dengan indeks labilitas yang memperlihatkan kondisi di wilayah Kalimantan Barat cenderung basah atau labil, kemudian dari data pengamatan observasi dan citra satelit terlihat langit rata-rata tertutup awan hingga mencapai $7 / 8$ okta per hari dengan didominasi oleh awan Cumulonimbus dan awan Konvektif tebal (Dense Cloud). Suhu puncak awan mencapai $-82^{\circ} \mathrm{C}$ dengan ketinggian lebih dari $16 \mathrm{~km}$. Kondisi udara menjadi labil dengan frekuensi badai guntur mencapai 80-90\%, dengan Curah hujan tertinggi yang terukur mencapai $212,0 \mathrm{~mm} /$ hari.

\section{Ucapan terima kasih}

Penulis mengucapkan terima kasih kepada Stasiun Meteorologi Supadio Pontianak dan Sekolah Tinggi Meteorologi, Klimatologi, dan Geofisika yang telah memfasilitasi dalam pembuatan tulisan ini. Penulis berharap tulisan ini dapat bermanfaat bagi pembaca.

\section{DaftarPustaka}

1. Ramage, Role of A Tropical Maritime Continent In The Atmospheric circulation, Monthly Weather Review Vol. 96 Issue 6 (1971) p. 365-370.

2. E. Aldrian, R. D. Susanto, Identification of Three Dominant Rainfall Region Within Indonesia And Their Relationship to Sea Surface Temperature, International Journal of Climatology, Wiley InterScience (2003).

3. Z. Achmad., Analisa dan Metode Prakiraan Cuaca, Pusat Pendidikan dan Pelatihan Meteorologi dan Geofisika (2009).

4. S. H. Prakosa, Kajian Dampak Borneo Vortex Terhadap Curah Hujan Di Indonesia Selama Musim Dingin Belahan Bumi Utara, Tesis Magister Institut Teknologi Bandung, Bandung (2013).

5. BPPT, 2013, Presipitasi dari Data TRMM (Tropical Rainfall Measuring Mission),http://www.wxmod.bppt.go.id/index.php/riset/presipitasi-trmm, diakses tanggal 2 Juli 2018. 